Jurnal Ilmu Sosial dan Pendidikan (JISIP)

Vol. 6, No. 1 Januari 2022

e-ISSN : 2656-6753, p-ISSN: 2598-9944

DOI: 10.36312/jisip.v6i1.2801/http://ejournal.mandalanursa.org/index.php/JISIP/index

\title{
Implementation Of Patent And Transfer Of Patent Rights According To Indonesian Patent Law
}

\author{
Abir Rafa Kamil \\ International Trade Law Master Candidate, Faculty of Law, University of Indonesia
}

\begin{tabular}{l}
\hline Article Info \\
\hline Article history: \\
Received 05 Januari 2022 \\
Publish 08 januari 2022 \\
\\
\\
\hline Keywords: \\
: license, patents, technology \\
transfer, intellectual property, \\
Indonesia, TRIPs, Patent \\
Rights transfer
\end{tabular}

Info Artikel

Article history:

Diterima 05 Januari 2022

Publis 08 januari 2022

\begin{abstract}
Indonesia as a member of the World Trade Organization ("WTO") is obliged to comply with the provisions stipulated in the Trade-Related Intellectual Property Rights Agreement ("TRIPs Agreement") especially regarding Patents; therefore, the Government of Indonesia regulates the provisions regarding Patents by Law Number 13 of 2016 concerning Patent which has been amended through Law Number 11 of 2020 Concerning Job Creation ("Indonesia Patent Law"). Article 20 of Indonesian Patent Law regulates that "the implementation of Patents must be implemented in Indonesia which can be done by making, importing, and licensing.". Related to the protection of patent rights granted, the state also hopes to transfer technology from Patent Holders; thus, their inventions can be produced and used without paying royalties to Patent Holders. However, the provisions regulated by the Government of Indonesia stipulate that the implementation of Patent can be carried out by importing, which will result in no transfer of technology from the Patent Holders to the state; thus, it will be detrimental to Indonesia. Therefore this paper will examine and explain the impact of applying Article 20 of the Indonesian Patent Law, especially regarding the implementation of Patent and transfer of Patent Rights.

\begin{tabular}{l}
\hline ABSTRAK \\
\hline Indonesia sebagai anggota World Trade Organization ("WTO”) wajib memenuhi \\
ketentuan yang ditetapkan dalam Trade-Related Intellectual Property Rigths \\
Agreement ("TRIPs Agreement") terutama mengenai Paten, oleh karena itu, \\
Pemerintah Indonesia mengatur ketentuan mengenai Patent melalui Undang- \\
Undang Nomor 13 Tahun 2016 tentang Paten yang telah diubah melalui Undang- \\
Undang Nomor 11 Tahun 2020 tentang Cipta Kerja ("UU Paten Indonesia”). \\
Pasal 20 UU Paten Indonesia mengatur bahwa "implementasi Paten harus \\
dilaksanakan di Indonesia yang dapat dilakukan dengan membuat, mengimpor, dan \\
lisensi.". Pada dasarnya terkait dengan perlindungan Hak Paten yang diberikan, \\
negara juga berharap untuk terjadinya peralihan teknologi dari Pemegang Paten \\
sehingga invensi mereka dapat diproduksi dan digunakan tanpa harus membayar \\
royalty kepada Pemegang Paten. Namun, ketentuan yang diatur oleh Pemerintah \\
Indonesia menetapkan bahwa implementasi Paten dapat dilakukan dengan \\
importasi yang mana hal tersebut tidakakan menghasilkan peralihan teknologidari \\
Pemegang Paten kepada negara sehingga akan merugikan Indonesia. Oleh karena \\
itu paper ini akan mengkaji dan menjelaskan dampak penerapan Pasal 20 UU \\
Paten Indonesia khususnya mengenai implementasi Paten dan transfer Hak Patent.
\end{tabular}
\end{abstract}

This is an open access article under the Lisensi Creative Commons AtribusiBerbagiSerupa 4.0 Internasional

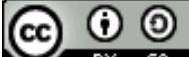

\section{Corresponding Author:}

Abir Rafa Kamil

International Trade Law Master Candidate, Faculty of Law, University of Indonesia

Email: rafaabir@gmail.com 


\section{INTRODUCTION}

Indonesia has implemented the provisions regarding the patent system for quite a long time, initially regulated through Law Number 6 of 1989 Concerning Patents ("Law No. 6/1989") which entered into force on August $1^{\text {st }}, 1991$. Whereas after the establishment of WTO in 1994, Indonesia officially joined as a member of WTO with the promulgation of Law Number 7 of 1994 Concerning Ratification of the Agreement Establishing the World Trade Organization ("Law No. 7/1994"). In this matter, WTO has a role in applying the regulation, standards, and conformity assessment used by countries and international organizations because almost all countries are currently members of WTO. Thus, each member country of WTO can give part of its economic sovereignty regarding international trade in full compliance with the rule of International Law as regulated by the WTO. In addition, the practices of international law also adhere to the pacta sunt servanda principle, which means that the agreement acts as a law for the parties; thus, every country that ratifies the WTO agreement must follow all the regulations regulated by WTO.

As a regulator in international trade, WTO regulates various things, one of which is the TRIPs Agreement. There are regulations regarding Intellectual Property Rights held through the TRIPs Agreement. As a member of the WTO, Indonesia also needs to regulate this matter. In this case, one form of Indonesia's commitment is to enforce Law No. 14 of 2001 on Patents ("Law No. 14/2001") as an adjustment to the provisions of the Indonesian Patent with the TRIPs Agreement so that harmonization occurs. However, in the course of Law No. 14/2001 is deemed necessary to be refined, therefore in 2015, the Government of Indonesia prepared an Academic Paper to discuss material changes and improvements to the patent system in Indonesia. Furthermore, from that Academic Paper, a new Patent Bill was created.

Whereas in 2016, when the House of Representatives (Dewan Perwakilan Rakyat) of the Republic of Indonesia discussed the Patent Bill at the Patent Bill Discussion Meeting on April 19 ${ }^{\text {th }}$, 2016 ("Forum"), The United States Chamber of Commerce submitted its assessment regarding the provision of the Patent Bill, especially the provision stipulated in Article 19. The provisions of Article 19 of the Patent Bill stipulate that:

“(1) Patent Holders are required to make products or use processes in Indonesia.

(2) Making a product or using a process as referred to in paragraph (1) must support technology transfer, absorption of investment and/or provision of employment opportunities."

This provision stipulates that the Patent Holder must make products or use processes in Indonesia. Making and using the process must also support technology transfer, absorption of investment, and/or the provision of employment opportunities.

The United States Chamber of Commerce is concerned that this provision will not be practical for foreign companies wishing to be considered as Patent Holders in Indonesia because, with this provision, foreign companies must manufacture their products or use processes in Indonesia, which will create high cost for foreign companies only have their patents recognized in Indonesia.

As mentioned above, WTO also regulates Intellectual Property Rights which are regulated in the TRIP's Agreement, which is the TRIPs Agreement is an integral part of the WTO agreement. Therefore, The United States Chamber of Commerce also states that the provisions of Article 19 of the Patent Bill are contrary to the Principle of Non-Discrimination as regulated in Article 27 paragraph (1) of the TRIP's Agreement, as follow:

"Subject to the provisions of paragraphs 2 and 3, patents shall be available for any inventions, whether products or processes, in all fields of technology, provided that they are new, involve an inventive step, and are capable of industrial application. Subject to paragraph 4 of Article 65, paragraph 8 of Article 70, and paragraph 3 of this Article, patents shall be available and patent rights enjoyable without discrimination as to the place of invention, the field of technology, and whether products are imported or locally produced." 
The provisions of Article 27 paragraph (1) of the TRIP's Agreement stipulate that Patents must be available and Patent Rights enjoyed without discrimination concerning where they were found, the field of technology, and whether the product is imported or not produced at the local level.

By looking at the provisions in Article 19 of the Patent Bill and Article 27 paragraph (1) of the TRIPs Agreement, it can be seen that the arguments form The United States Chamber of Commerce which state that the provisions of Article 19 of the Patent Bill are contrary to the provisions of Article 27 Paragraph (1) of the TRIP's Agreement are acceptable. However, despite criticism from The United States Chamber of Commerce, Indonesia still passed the Patent Bill through Law Number 13 of 2016 Concerning Patent.

The Indonesian government argues that the enforcement of the Law Number 13 of 2016 Concerning Patent will encourage Indonesia inventors because it provides legal certainty, which will lure Indonesian inventors who are abroad to make and process patents in Indonesia; moreover, this is a positive step to protect the public from counterfeit products.

Seeing the attitudes and arguments of the Indonesian Government which enforced Law Number 13 of 2016 Concerning Patent without changing or revoking the provisions of Article 20 (previously Article 19 in Patent Bill), the American Chamber of Commerce in Indonesia ("AMCHAM INDONESIA") stated that although the Law Number 13 of 2016 Concerning Patent was designed for Indonesia inventors, some of the contents of Law Number 13 of 2016 Concerning Patent were deemed challenging foreign patent owners, especially from the US. This is because Law Number 13 of 2016 Concerning Patent requires Patent Holders to produce patented products or take advantage of their patent processes in Indonesia. According to Indonesian Law Number 13 of 2016 Concerning Patent, these activities must include technology transfer, increasing investment, and creating jobs.

After 4 (four) years of the Law Number 13 of 2016 Concerning Patent in effect, the Indonesian Government finally changed the provisions of Article 20 of the Law Number 13 of 2016 Concerning Patent through Article 107 point 2 of the Law Number 11 of 2020 so that the provisions of Article 20 of the Law Number 13 of 2016 Concerning Patent became as follows

“(1) Patents must be implemented in Indonesia.

(2) The implementation of the Patent as referred to in paragraph (1), is as follows:

a. the implementation of a product-Patent which includes manufacturing, importing, or licensing the patented product;

b. the implementation of a process-Patent that includes manufacturing, importing, or licensing products generated from the patented process;

c. the implementation of a method-, system- and utilization-Patent which includes manufacturing, importing, or licensing products generated from the patented method, system, and utilization."

The amendments made by the Indonesian Government did make the provisions of Article 20 of the Indonesia Patent Law to be in harmony with the provisions of Article 27 paragraph (1) of the TRIPs Agreement. Still, Article 20 of the Indonesia Patent Law resulting from the implementation of Patent in Indonesia can be made without any transfer of technology because the Patent Holders can export the invented products to Indonesia (imported by Indonesia). However, on the other hand, the TRIPs Agreement and the Indonesian Patent Law also stipulates that the transfer of Patent Rights can also be carried out with a license; the licensing system is different from importation which can lead to technology transfer because the licensee gets the right to produce the product (in case of product-Patent) and can use the production process (in case of process-Patent).

Therefore related to that, this paper will criticize the provisions of Article 27 paragraph (1) of the TRIPs Agreement and Article 20 of the Indonesian Patent Law, especially regarding the impact of the implementation of Patents through the import method and what effect it will have on Indonesia 
if these provisions are enforced, besides that this paper will also explain the licensing system that applies in Indonesia and the benefit of it.

\section{METHODS}

\subsection{Research Method}

This research uses a monodisciplinary approach; in the development of legal scholarship, it is clear that it has limitations, especially to answer the complexities of problems in society. When methodologically (research) is imposed as a prescription, it is possible to give birth to insensitivity or ineffectiveness in the reality of society. This prescription is self-limiting; it nullifies the community in which the law is born and operates. So that a monodisciplinary study, even though it is needed to fulfill an intrinsic analysis of legal rules, requires the development of a study within the scope of legal scholarship, which is no longer monodisciplinary but interdisciplinary.

The statutory approach is carried out by reviewing all laws and regulations related to the legal issues being handled, namely, rules related to the Patent based on Indonesian Law No. 11/2020, Indonesian Law No. 13/2016, and Trade-Related Intelectual Property. In addition, the historical approach is carried out by collecting and reviewing concepts regarding the legal issues at hand.

\subsection{Legal Material}

The legal materials used are primary legal materials and secondary legal materials. Primary legal materials are legal materials that have authority (authoritative). Primary legal materials can be in the form of statutory regulations. Then the primary legal material that has control other than the legislation is a court decision which is the concretization of the legislation. The primary legal material used in this study is Indonesian Law No. 11/2020, Indonesian Law No. 13/2016, Trade-Related Intelectual Property Rights. Meanwhile, secondary legal materials are all publications on the law, unofficial documents. These publications consist of textbooks that discuss one and/or several legal issues, including legal theses and dissertations. Then legal journals and comments on judge decisions are also secondary legal materials.

\subsection{Data Collection Method}

The data collection used in this research is a literature study. Literature study by collecting various primary and secondary legal materials covering multiple laws and regulations, books, legal journals, to data via the internet.

\section{RESULT AND DISCUSSION History of Patent}

As explained above, the regulation of the patent system in Indonesia has been going on since 1981, and up to now, this regulation has been amended several times. When compared with the history of the patent system in the World, Indonesia is still classified as "young" because if it is examined further, it can be seen that the history of patents began in the European region in the XV century, in 1474, the Republic of Venetian started to offer exclusive rights to inventors and entrepreneurs who had inventions or introduced new technologies in Venice, to attract skilled artisan, as time went on, other European territories copied the patent system provisions imposed by the Republic of Venetian to promote economic development and is often used to gain political and financial support.

England is one of the countries that pioneered the enforcement of patent provisions, at first, the England Parliament enacted the Statute of Monopolies in 1624 as a reaction to abolishing and limiting the Crown's use of royal privileges or "letters patents" to grant monopolies over specific industries. The Statue of Monopolies regulates that patents can only be granted for new inventions for not more than 14 years. 
Similar to England, in this case, the United States has regulated the patent system since 231 (two hundred and thirty-one) years ago. The United States Congress enforces patent provisions through "An Act to promote the progress of useful Arts." The first patent protection was granted to Samuel Hopkins for "making Pot ash and Pearl ash by a new Apparatus and process.". This provision laid the groundwork for the world's first modern patent system that was instrumental in driving technological progress and economic growth in the United States.

The development of Intellectual Property Law in the world can be categorized into 3 (three) periods; the first period starting in the mid-19th century where several countries on the European and American continents such as Britain, The United States, France, Italy, Germany, Russia, Netherland, Spain, Argentina, Mexico, Brazil, and Chile began to draft patent legislation.

The second period ran from 1850 to early 1880, starting with the introduction of patent provisions in the British and French colonies, several countries in Latin America continued to draft their patent regulation, such as Uruguay, which began to enforce patent regulation in 1853, and Venezuela (1878), during this period the colonial powers used various methods to develop legal provisions to protect the invention in their colonies.

Finally, the third period began in 1880. An acceleration marked this period in the spread of patent provisions; several European countries such as Switzerland and Denmark eventually adopted patent laws; moreover, this spread also occurred in African countries due to British and French colonial powers. Besides that, in this period, the regulation regarding Intellectual Property Rights is deemed insufficient if it's only regulated domestically; thus, countries try to control intellectual property laws internationally marked by the establishment of the Paris Union in 1883 and the Convention on Patents and Trademarks ("Paris Convention"), furthermore, in 1886 the Berne Union and the Convention for the Protection of Literary and Artistic Works ("Berne Convention") were also created.

Countries are interested in expanding the scope of intellectual property beyond the Paris and Berne Conventions due to the lack of solid law enforcement provisions for national judicial, administrative bodies and a lack of adequate and binding dispute resolution mechanisms that states can use in the event of a dispute. This impulse contradicts the increasing assertiveness of some larger developing countries interested in maintaining policy space to adapt their domestic provisions to suit their national interests and led to serious debate about intellectual property's role in driving development from the 1960s.

Around the 1960s, several developing and newly independent countries began to advocate for establishing a trade institution outside the General Agreement on Tariffs and Trade ("GATT"), which argued that it was insufficient to meet the needs of developing newly independent countries. There is a debate about international trade, primary trade-in commodities, and economic relations between developing countries and developed countries. This is in conjunction with the efforts of developing countries to form the United Nations Conference on Trade and Development ("UNCTAD") in 1964. In this case, developed countries were against UNCTAD, as a form of retaliation by developed countries to deepen their commitment to intellectual property, which began through the Paris and Berne conventions, developed countries proposed the formation of the World Intellectual Property Organization ("WIPO") in 1967, to regulate the Paris Convention and Berne Convention, furthermore to promote harmonization of intellectual property laws.

Furthermore, in 1986, the Uruguay Round of the trade negotiations began. Corporate networking was achieved globally through collaboration between individuals, companies, and group businesses in the United States and Europe, and Japan. This has proven to be very effective in uniting stakeholders on issues of mutual concern, resulting in the sense of optimism and high determination to adopt an Intellectual Property Rights agreement that supports the business plan. 
In the final stages of the Uruguay Round negotiations in the first few years of the 1990s, most developing countries had stopped opposing the inclusion of the TRIPs Agreement under the soon-to-be WTO. In April 1994, 123 (one hundred and twenty-three) countries signed the Marrakesh Agreement, which became the premise for the World Trade Organization (WTO). The Marrakesh Agreement contains about 60 agreements, annexes, decisions, and understandings, one of which is TRIPs. The Agreement on Trade-Related Aspects of Intellectual Property Rights (TRIPs), which became effective in 1995, with the implementation of the TRIPs Agreement, becomes a requirement for every WTO Member to apply the provisions regarding Intellectual Property Rights by the TRIPs Agreement. The TRIPs Agreement represents a significant erosion of much of the policy space in the Paris Convention, such as the freedom of WTO Members to determine the duration of patents in national law and to limit patents of pharmaceutical products.

Suppose you look at the historical development of Patent Rights above. In that case, it can be seen that Patents are a monopoly right granted by the state on a product or process created by a person so that person can enjoy the economic rights of his invention. As time goes by, the world of international trade is growing, wherein its development, countries put forward the concept of Free-Trade, which is contrary to the nature of Patent Rights, a monopoly. Thus, the provisions of Patent Rights are regulated in such a way as to continue to provide monopoly rights to Patent Holders while upholding the Free-Trade concept.

\section{TRIPs Agreement Principle and Objectives}

From the history of the development of the provision of Intellectual Property Rights as described in the previous section, it can be seen that in fulfilling the needs of Intellectual Property Rights protection for the Patent Holders and the interest of countries, TRIPs Agreement stipulates several basic principles in implementing its rules. These principles are stated in TRIPs Agreement, namely:

\section{Free to Determine Principle}

This principle gives the members of this agreement freedom to determine their respective procedures or methods that are deemed appropriate to implement the provisions contained in Trips into their national laws (Article 1 TRIPs Agreement). However, the existence of this principle does not mean that each country can unilaterally interpret the provisions of TRIPs; this provision implies that the regulation of Intelectual Property Rights in the TRIPs Agreement only concerns issues relating to international trade or cross-border in essence. Meanwhile, more specific arrangements are left entirely to each member country.

\section{National Treatment Principle}

Like the understanding of the National Treatment principle stipulated in WTO, this principle requires each member to provide the same Intellectual Property Rights Protection between its citizen and citizens of other member countries (Article 3 paragraph 1 TRIPs Agreement). This principle not only applies to individuals but also applies to legal entities.

\section{Most Favoured Nation Principle}

This principle requires each member to provide each other with Intellectual Property Rights protection and equal treatment between members' countries (Article 4 TRIPs Agreement). These three principles are applied to fulfill the objectives of the TRIPs Agreement; related to these objectives Amy Kapezynski in her paper, states that one of the objectives of the TRIPs Agreement is to create harmonization in terms of regulating Intellectual Property Rights in the world to become stronger, especially for the developing countries and least developing countries.

Furthermore, the purpose of the implementation of the TRIPs Agreement is to promote innovation, transfer, and dissemination of technology, which is these objectives are is stated in Article 7 of TRIPs Agreement which stipulates that:

"The protection and enforcement of intellectual property rights should contribute to the promotion of technological innovation and the transfer and dissemination of technology, to the 
mutual advantage of producers and users of technological knowledge and in a manner conducive to social and economic welfare, and to a balance of rights and obligations."

It can be seen that, in essence, TRIPs Agreement prioritizes innovation and technology transfer that occurs from an invention made by Patent Holders to the State (for example) to create conduciveness for social and economic welfare while maintaining the interest of both parties for mutual benefit.

About Article 7 as an objective of the TRIPs Agreement, other principles also support these objectives, namely the principle of public interest as regulated in Article 8 of the TRIPs Agreement as follows:

"1. Members may, in formulating or amending their laws and regulations, adopt measures necessary to protect public health and nutrition, and to promote the public interest in sectors of vital importance to their socio-economic and technological development, provided that such measures are consistent with the provisions of this Agreement.

2. Appropriate measures, provided that they are consistent with the provisions of this Agreement, may be needed to prevent the abuse of intellectual property rights by right holders or the resort to practices which unreasonably restrain trade or adversely affect the international transfer of technology."

It can be seen from the provisions of Article 8 of the TRIPs Agreement that WTO members have the right to make or enforce laws and regulations to protect public health and also to promote public interest in sectors that the country considers essential for their socio-economic and technological development as well as long as these laws and provisions are still in harmony with the provisions of the TRIPs Agreement. In addition, the principle of public interest is also needed to prevent the abuse of intellectual property rights by carrying out unreasonable practices that are detrimental to international technology transfer.

In essence, the TRIPs Agreement transformed the international intellectual property system from a patchwork system to a global supranational code; articles 1 to Article 8 of the TRIPs Agreement describe the objectives and principles set out in the TRIPs Agreement, which are the central part of the implementation and interpretation of the TRIPs Agreement, these objectives and principles become more important because of the revolutionary nature of the TRIPs Agreement. Furthermore, K. Yu Peter stated in his Article that Article 7 and Article 8 the of TRIPs Agreement could act as a balance of interest at the multilateral level to replace the balance that is traditionally carried out at the national level; this provision focuses in particular on 5 (five) ways in which these provisions can be used effectively as follows:

\section{A Guiding Light}

In essence, Articles 7 and 8 give significant measures to guarantee that the WTO Panel focuses on the compromises established during the TRIPs discussions between rich and developing nations. Even if the WTO Panel disregards such an agreement, both sections provide the linguistic proof that the Appellate Body requires to correct any mistake.

\section{Shield}

This function is related to the part of Article 7 and Article 8, which in this case, member States use flexibilities that the TRIPs Agreement has made. The purpose of this provision is to provide necessary protection given the fact that developed countries have become the primary users of the WTO dispute settlement process.

Sword

Articles 7 and 8 can be employed in six distinct ways as attacking tools. First, while the provisions may not provide a legal basis for challenging developed country intellectual property laws and policies in the WTO dispute settlement process, both provisions can be used to strengthen other operative provisions that promote social and economic welfare or help maintain the intellectual property system's balance. Articles 7 and 8 can help enhance the limitations and 
exceptions in Articles 27 and 31 patent context. For example, Articles 27.2 and Article 27.3 lay forth the criteria for disqualifying innovations from patentable status.

\section{Bridge}

Articles 7 and 8 can act as a beneficial bridge between the TRIPS regime and many other regimes (such as biodiversity and the food and agriculture) that may be affected by intellectual property the protection and enforcement of intellectual property rights, the WTO Dispute Settlement Body has acknowledged that intellectual property protection overlaps the security under other international treaties, in India-Patent Protection for Pharmaceutical and Agricultural Chemical Products, the WTO Panel also recognized that the TRIPS Agreement "is an integral part of the WTO system, which itself builds upon the experience over nearly half a century" under the GATT.

Seed

Articles 7 and Article 8 of TRIPs Agreement may be used as a seed for the event of recent norms each among and while not the international intellectual property regime., they'll provide the required language or give direction for the possibility of those new norms, they additionally facilitate cue the accord drafters of the character, scope, and objectives of intellectual property norms.

Since their creation and limited application within the period of the WTO, Article 7 and Article 8 of the TRIPs Agreement have attracted growing attention from policymakers, commentators, intergovernmental organizations, and non-governmental organizations. Legally, the two provisions play vital roles in interpreting and implementing the TRIPS Agreement. Economically, they facilitate innovation, technology transfer, and knowledge production while promoting social and economic welfare and development goals. Politically, they supply the muchneeded balance to make the Agreement a legitimate bargain between developed and lessdeveloped countries. Structurally, the two provisions bridge the gap between the TRIPS regime and other international regimes.

\section{Types Of Patents in Indonesia}

Apart from explaining the international patent history, in this case, Indonesia adopts internationally applicable patent principles into its domestic regulations, namely through the Indonesian Patent Law. There is no division of patents in the international Patent provisions regulated in the TRIPs Agreement; however, the Government of Indonesia divides patents into 3 (three) types, namely Patent-product, Patent-process, and Patent-methods. There is no further explanation in the Indonesian Patent Law regarding what is meant by Patent-product, Patentprocess, and Patent-methods, but if we carry out a grammatical interpretation, what is meant by a Patent-product, Patent-process, and Patent-methods are as follows:

\section{Patent-product}

Based on the Black's Law Dictionary $2^{\text {nd }}$ edition, the definition of product is as follows: "A good distributed commercially that is (1) tangible personal property, (2) the result of a fabrication or production process, and (3) passed through the distribution channel before the consumption of the good"

It can be seen that a product is the result of a process; therefore, what is meant by a Patentproduct is Patent protection granted to someone who produces a product from their invention.

\section{Patent-process}

Apart from the product, Black's Law Dictionary also defines what is meant by process, namely "alone would have been applicable, either in the same or analogous cases, if summary proceedings had not been available.". The definition explains that the process can be applied in one case; thus, Patent-process protects patent rights granted to someone for the process that he created (invention). 


\section{Patent-method}

Lastly, Black's Law Dictionary also provides definitions related to what is meant by "method" as follows:

"In patent law. "Engine" and "method" mean the same thing and maybe the subject of a patent. Method, properly speaking, is only placing several things or performing several operations, in the most convenient order, but it may signify a contrivance or device."

From this definition, it is known that method is a way that is part of the process of making a product; thus, what is meant by Patent-method is the protection of patent rights granted to someone for creating a new method in a strategy to make products.

The explanation regarding the definition of the patent types regulated by the Indonesian Government above is the result of a grammatical interpretation that I did; it would be better if the Indonesian Government could provide such explanation related to these types of patents to create legal certainty for inventor and other parties interested.

Patent Implementation And Transfer Of Rights System In Indonesia

As explained in the previous section that a Patent is a monopoly right granted to a person for his invention, which over time, the nature of the monopoly begins to be eroded by the Free Trade concept, related to this matter, not only to protect the interests of the Patent Holder by the principle that stipulated in TRIPs Agreement as explained before, the interests of the state are also protected by the provisions of the international Patent as regulated in the TRIPs Agreement. Article 27 paragraph (1) TRIPS Agreement stipulates that:

"......patents shall be available and patent rights enjoyable without discrimination as to the place of invention, the field of technology and whether products are imported or locally produced."

It can be seen that the TRIPs Agreement stipulates that patent rights can be enjoyed without discrimination which can be done by importing or producing locally. The Indonesian Government also adopted this provision through Article 20 of the Indonesian Patent Law, which stipulates that Patents must be implemented in Indonesia and can be implemented using manufacturing, importing, and licensing methods.

\section{Implementation of Patent in Indonesia Importation}

It is known that import is the movement of goods into the country from abroad. In my opinion, this import method will be detrimental to the state because this import method does not result in the transfer of technology from the Patent Holder to the country that imports the product of the invention created by the Patent Holder. In this case, neither the TRIPs Agreement nor the Indonesian Patent Law further explains what is meant by Importation. It can result in a technology transfer in which it is in the state's interest.

Moreover, there is confusion if you look at the distribution of the types of patents carried out by the Indonesian Government which have an impact on technology transfer; if further examined, the import method can only be carried out on Patent-products because, as you see the definition of importation itself is "a movement of goods from one country to another" thus that cannot be applied to Patent-process and Patent-method which incidentally are not goods.

In this case, the importation of Patent-products does not transfer technology to the importing country because the importing country only buys Patent-product; thus, it only gives rise to the right to use the product, it does not give the right to produce the product in its country; therefore the import method does not provide benefits for the importing country.

Manufacturing

In this case, the Government of Indonesia did not provide further explanation on what is meant by manufacturing, but Black's Law Dictionary defines that manufacturers are: 
"Any useful product made directly by human labor, or by the aid of machinery directed and controlled by human power, and either from raw materials or materials worked up into a new form. Also, the process by which such products are made or fashioned."

It can be seen that manufacturing is the process of making a product from raw materials into a product that can be used and sold; this method is quite effective in transferring technology from the Patent Holder to the country. This is because the state is given the right to use the invention made by the patent holder; therefore, it can cause a technology transfer. Furthermore, this method can be used in both Paten-product, Patent-process, and Patent-method, but keep in mind that manufacturing is the process of making a product, therefore to get the right to produce the product, the country or local company in that country needs to get a prior license from the Patent Holders which can be granted by making a license agreement.

\section{Transfer of Patent Rights according to Indonesian Patent Law}

The two previous methods, namely importation and manufacturing, do not transfer Patent Rights, based on Article 74 of Indonesian Patent Law which stipulates that Patent Rights can be transferred due to inheritance, grant, will, waqf. Written agreement (license), but this paper will only discuss more deeply the transfer of Patent Rights through a written agreement (license).

A License is a permit granted by a Patent Holder, both exclusive and non-exclusive, to a licensee based on a written agreement to use a Patent that is still protected for a certain period and under certain conditions, to carry out his Patent about making, using, selling, importing, leasing, delivering, or providing for sale or lease, and using the process of production.

The Indonesian Government regulates further regarding the License in the Regulation of The Government of The Republic Of Indonesia Number 36 of 2018 Concerning The Recordation Of Intellectual Property Licensing Agreements ("PP No. 36/2018"), which in this case is regulated that the License Agreement must be in written form and must have Bahasa Indonesia version if it is made in a language other than Bahasa Indonesia.

In addition, in making the License Agreement, the Indonesian Government also regulate that the License Agreement is prohibited from containing provisions that can harm the Indonesian economy and the Indonesian national interest, have restrictions that inhibit the ability of Indonesia nation in the transfer, mastery, and development of technology, resulting in unfair competition, and/or contrary to the provisions of the laws and regulations, religious values, decency, and public order.

The License Agreement made in Indonesia must be recorded by the Minister of Law and Human Rights ("MoLHR"), which in the License agreement shall at least contain:

1. The date, month, year, and location of the signing of the Licensing agreement;

2. The name and address of Licensor dan Licensee;

3. The object of Licensing agreement;

4. Provisions regarding exclusive or non-exclusive License, including sublicense;

5. The term of Licensing agreement; f. the area where Licensing agreement applies; and

6. The party undertakes to payment of annual costs for patents.

Moreover, if the Licensor and Licensee are foreign nationals or residing outside the territory of Indonesia, the record of the License Agreement must be submitted by an Authorized.

In terms of requesting recording a License Agreement, the Licensee must attach at least the copy of Licensing agreement; official excerpt of the patent certificate, mark certificate, industrial design certificate, integrated circuit layout design certificate, proof of ownership of the relevant creation or right, or proof of ownership of trade secret that is being licensed and is still valid; power of attorney, if the application is submitted through a Proxy; and cost payment receipt. After all documents are declared complete by MoLHR, the MoLHR will record the License Agreement in the General List of the Intellectual Property Rights License Agreement and announce it on the official news of the patent. 
Apart from the agreement between Licensors and Licensees, licenses can also be given to permissions using a compulsory license method. The Indonesian Government will appoint the licensee but remains based on a prior application. Moreover, this mandatory license is nonexclusive so that several local companies in the country can own the License; the settings of this compulsory license are regulated in the Regulation of the Minister of Law and Human Rights of the Republic of Indonesia Number 30 of 2019 concerning Procedures for Providing Compulsory Licenses Patent as amended by Regulation of the Minister of Law and Human Rights of the Republic Indonesia Number 14 of 2021.

There is a clear difference between implementing Patents and the transfer of Patent Rights. In this case, the implementation of a patent can be used when the rights of the patent have been transferred (through a License Agreement or Compulsory License). The performance can be done by importing and manufacturing. In my opinion, the manufacturing method is more effective than import because the manufacturing method is accurate, resulting in the occurrence of technology transfer.

\section{CONCLUSION}

In essence, the Patent is the right of the monopoly of Patent Holders to enjoy the economic benefits of the invention, which is where the monopoly rights are protected by international and domestic law by countries where the Patent is registered. Still, in this case, in addition to defending the interests of Patent Holders, the governments also have an interest in obtaining technology from the invention created by the Patent Holder. Therefore, international regulation and domestic regulations of countries also regulate that the Patent Rights can be transferred in several ways, one of which is by providing a license by Patent Holder to the government or the local company of those countries based on a License Agreement.

\section{SUGGESTION}

This License is quite effective for the state in fulfilling its interest, namely the technology transition. The given License makes the country or local company produce its products from the invention carried out by Patent Holders. Thus it does not need to wait until the protection of Patents from the state is ended to enjoy the new technology or product.

\section{ACKNOWLEDGMENTS}

I thank all the people closest to me who have always supported and provided suggestions and input for this research.

\section{BIBLIOGRAPHY}

\section{Legal Documents}

Indonesia, Peraturan Menteri Hukum dan Hak Asasi Manusia tentang Prosedur Untuk Melaksanakan Lisensi WajibPerjanjian (Minister of Law and Human Rights Regulation regarding Procedure for Providing Compulsory License), PERMENKUMHAM. No 30 Tahun 2019, (MoLHR Regulation Number 38 of 2019).

Indonesia, Peraturan Menteri Hukum dan Hak Asasi Manusia tentang Perubahan Atas Peraturan Menteri Hukum dan Hak Asasi Manusia Nomor 30 Tahun 2018 Tentang Tata Cara Pemberian Lisensi Wajib Paten (Minister of Law and Human Rights Regulation regarding the Amendment of Minister of Law and Human Rights Regulation regarding Procedure for Providing Compulsory License), PERMENKUMHAM. No. 14 Tahun 2021, (MoLHR Regulation Number 14 of 2019).

Indonesia, Peraturan Pemerintah tentang Perjanjian Lisensi (Law regarding License Agreement), PP. No 38 Tahun 2018, LN No. 115 Tahun 2018 (Government Regulation Number 38, SG No. 115 of 2018). 
Indonesia, Undang-Undang tentang Cipta Kerja (Law regarding Job Creation), UU No. 11 Tahun 2020, LN No. 245. Tahun 2020 (Law Number 11 of 2020, SG No. 245 of 2020).

Indonesia, Undang-Undang tentang Paten (Law regarding Patents), UU No. 13 Tahun 2016, LN No. 5922. Tahun 2016 (Law Number 13 Year 2016, SG No. 5922 of 2016).

National Legal Development Agency, Ministry of Law and Human Rights, the Academic Paper on the Draft Law on Amendment to the Law of the Republic of Indonesia Number 13 of 2016 concerning Patent, (2019)

WTO, the Agreement on Trade-Related Aspects of Intellectual Property Rights, Marrakesh Agreement Establishing World Trade Organization, Annex 1C, 1869 U.N.T.S 299, 33 I.L.M. 1197 (April 15, 1994)

\section{Books}

Bossche, Peter Van den, The Law and Policy of the World Trade Organization: Text, Cases and Materials, Cambridge: Cambridge University Press, 2013.

Gabriel, Galvez-Behar. 2020. "The 1883 Paris Convention and the Impossible Unification of Industrial Property." In Patent Cultures: Diversity and Harmonization in Historical Perspective, 38-68. Cambridge Unversity.

International Monetary Fund. 1995. "The Uruguay Round and the Arab Countries." Seminar of International Monetary Fund. Kuwait: International Monetary Fund. 6.

Kusumaatmadja, Mochtar, and Etty R. Agoes. 2003. Pengantar Hukum Internasional. Bandung: PT. Alumni.

Partiana, I Wayan. 2002. Hukum Perjanjian Internasional. Bandung: CV. Manda Maju.

Sood, Muhammad, Hukum Perdagangan Internasional, Depok: Rajawali Pers, 2018.

Articles

Adolf, Huala. 2001. "TRADE-RELATED ASPECT OF INTELLECTUAL PROPERTY RIGHTS AND DEVELOPING COUNTRIES." The Developing Economies 49-84.

Baker, B., and T. Avafia. 2011. "The Evolution of IPRs From Humble Beginnings to the Modern Day TRIPS-plus Era: Implications for Treatment Access." Third Meeting. Global Commission on HIV. 8.

Barziah, Nurul. 2017. "THE DEVELOPMENT OF ASEAN INTELLECTUAL PROPERTY RIGHTS LAW; FROM TRIPS COMPLIANCE TO HARMONIZATION ." Indonesian Law Review 95-112.

Chopra, Hitesh, and Sandeep Kumar. 2014. "Intellectual Property Protection and Rights: Historical and Current Perspective." International Journal of Pharmacy and Pharmaceutical Science 572-578.

Kapenzynki, Amy. 2009. "Harmonization and Its Discontents: A Case Study of TRIPs Implementation In India's Pharmaceutical Sector." California Law Review 1571-1649.

Moser, Petra. 2013. "Patents and Innovation: Evidence from Economic History." Journal of Economic Perspectives 23-44.

Peter, K. Yu. 2009. "The Objectives and Principle of the TRIPS Agreement." Houston Law Review 980-1016.

Purba, A. Zen Umar. 2014. "TRIPs and Developing Countries." Indonesia Journal of International

Web Sites Law 245-268.

Klik Legal. 2017. Klik Legal. May 16. Accessed May 17, 2021. https://kliklegal.com/kisahkeberatan-kamar-dagang-amerika-terhadap-pasal-20-uu-paten/.

Silaban, Mary R. 2016. AMCHAM INDONESIA (American Chamber of Commerce In Indonesia $\begin{array}{llllll}\text { Since 1971). August 9. Accessed } & \text { May }\end{array}$ https://www.amcham.or.id/en/news/detail/patent-bill-finally-becomes-law. 